\title{
Comparison of Electromyographic Activity of Anterior Tibial Muscles and Long Fibular in Athletes With and Without Chronic Ankle Instability
}

\section{Comparação da Atividade Eletromiográfica dos Músculos Tibial Anterior e Fibular Longo em Atletas com e sem Instabilidade Crônica de Tornozelo}

\author{
Giovanna Piai Cezar ${ }^{\mathrm{a}}$; Barbara Pasqualino Fachin ${ }^{\mathrm{b}}$; Christiane de Souza Guerino Macedo*ab \\ aState University of Londrina, Physiotherapy Course. PR, Brazil.

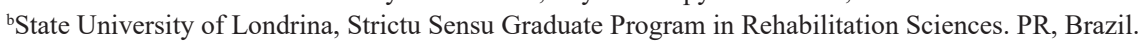 \\ *E-mail: chmacedouel@yahoo.com.br \\ Recebido em: 23/09/2020 \\ Aprovado em: 03/12/2020
}

\begin{abstract}
Chronic ankle instability (ICT) is common in jumping sports, may alter muscle recruitment, result in functional limitations and recurrence of sprains in this joint. The purpose of the study was to compare the muscle recruitment of the anterior tibial and long fibular muscles of athletes with and without chronic ankle instability by means of surface electromyography. Thirty-four athletes were recruited, divided into instability group (GI: $n=14$ ) and control group (GC: $n=20)$, of both sexes and from different sport modalities, aged between 18 and 27 years old, history of ankle sprain in the last 12 months and functional limitation established by the Cumberland Ankle Instability (CAIT) questionnaire, the recruitment of the anterior tibial and long fibular muscles was analyzed by surface electromyography during the lunge exercise. The results for GI and GC were, respectively: age 21.3 \pm 2.88 and 22.4 \pm 3.25 , height 1.77 \pm 0.10 and 1.74 \pm 0.08, CAIT 17[12.2-19] and 29.5 [27-30] (p<0.001). The anterior tibial and long fibular muscle recruitment in GI was 111.1[62.5-165.4] and 68.2 \pm 29 , respectively and in GC 106.8[79.8-230.5] and $54.4 \pm 26.4$, without significant difference. ICT did not interfere in the recruitment of the anterior tibial and long fibular muscles during the lunge exercise in athletes.
\end{abstract}

Keywords: Ankle. Sprains and Strains. Health Evaluation.

\section{Resumo}

A instabilidade crônica do tornozelo (ICT) é comum em esportes de saltos, pode alterar o recrutamento muscular, resultar em limitações funcionais e recidivas de entorses nesta articulação. O objeto do estudo foi comparar o recrutamento muscular dos músculos tibial anterior e fibular longo de atletas com e sem instabilidade crônica de tornozelo por meio da eletromiografia de superficie. Foram recrutados 34 atletas, divididos em grupo instabilidade (GI: $n=14)$ e grupo controle (GC: $n=20)$, de ambos os sexos e de diferentes modalidades esportivas, com idade entre 18 e 27 anos, história de entorse de tornozelo nos últimos 12 meses e limitação funcional estabelecida pelo questionário Cumberland Ankle Instability (CAIT), o recrutamento dos músculos tibial anterior e fibular longo foi analisado pela eletromiografia de

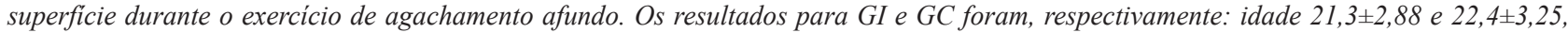

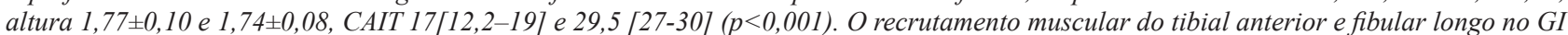

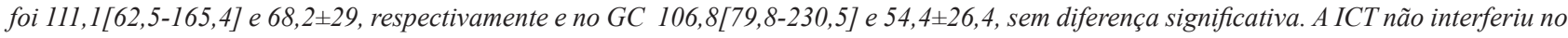
recrutamento dos músculos tibial anterior e fibular longo durante a realização do exercício de agachamento afundo em atletas.

Palavras-chave: Tornozelo. Entorses e Distensões. Avaliação em Saúde.

\section{Introduction}

Among the most common sports injuries is the lateral ankle sprain (LAS) ${ }^{1}$. It is estimated that the annual incidence rate of this lesion is 2.15 to 1.000 people for the general population, with an increase of this rate to 58 sprains per 1,000 athletes ${ }^{2}$. It is believed that ICT is based on lateral ankle sprain (LAS), it is one of the most common lesions in sport ${ }^{3}$, it happens by the combined movement of plantar flexion and ankle inversion ${ }^{4}$, and the condition can be maintained for more than 12 months after the first episode ${ }^{4-6}$. The primary causes are mechanical instability (anatomical changes) and functional (subjective sensation of ankle instability) or the combination of both.

After a first sprain, the athlete is more susceptible to underlying lesions, and often develops symptoms such as chronic pain, edema and functional instability ${ }^{7}$. In addition, about 10 to 30 percent of athletes with LAS develop chronic ankle instability (ICT) ${ }^{8}$, which can cause persistent limitations such as neuromuscular and proprioceptive deficits, reduction in the ability to control balance and coordination, decrease in position direction in the ability to control balance and coordination, decrease in joint position and delayed activation of fibular muscles, in response to sudden inversion disorders ${ }^{7}$, associated with the frequent occurrence of new sprains ${ }^{9}$, with a reduction in quality of life and sports performance ${ }^{10}$ in addition to causing early osteoarthritis ${ }^{11}$.

An imbalance in the long and anterior tibial fibular muscles activity is observed after an LTA, where the anterior tibial muscle recruitment seems to be greater than that of the long fibular muscle ${ }^{8}$, which favors the ankle and foot inversion movement. According to Thain ${ }^{12}$, the long 
fibular muscle during contraction would be responsible for preventing excessive ankle inversion and would protect the articulation from a sprain. Thus, when there are deficits in muscle recruitment, the internal strength generated in the ankle joint may not be effective to counterbalance the external strength, and results in instability and joint injury ${ }^{13}$. In this sense, Thompson et al. ${ }^{3}$ evidenced that individuals with ICT present deficits in strength time of muscle reaction and postural control.

Many studies seek to understand the ankle muscle response during a sports activity through electromyography in athletes with and without ICT, to obtain a better treatment ${ }^{14}$ and even to analyze the rehabilitation efficiency ${ }^{15}$. In a study by Koldenhoven et $\mathrm{al} .{ }^{4}$ a greater activation of the long fibular was found during the gait of individuals with ICT, and even with the lateral sprains protection carried out by evertor muscles, this population presented recurrent lesions ${ }^{15}$. Donnelly et al. ${ }^{16}$ found important force deficits in the long and short fibular muscles, responsible for the eversion movement in the ICT group in different ankle positions. Li et al. ${ }^{5}$ and Suda et al. ${ }^{14}$ found a reduction in the long fibular activity and a higher recruitment of the anterior tibial in the pre-landing phase, and established that rehabilitation should stimulate a greater long fibular muscle recruitment. It is complemented that for the treatment and prevention of inverted sprains, the coordinated contraction of the anterior tibial and long fibular muscles should be stimulated ${ }^{12}$.

The hypothesis of the present study is that athletes with chronic ankle instability present less muscle recruitment of the anterior tibial and long fibular muscles when compared to athletes without ICT, since the literature confirms the force deficit and shorter muscle reaction time in these individuals. Thus, the objective of this study was to compare the anterior tibial and long fibular muscles recruitment in athletes with and without ICT by means of surface electromyography during a dynamic weight discharge activity at the ankle and foot joint.

\section{Material and Methods}

This a is cross-sectional study, approved by the Ethics and Research Committee from the State University of Londrina (Opinion number 2.771.026).

\subsection{Sample}

The sample was calculated by the Power and sample Size program, considering alpha of 0.05 , power of 0.8 and the values of mean and standard deviation of individuals with footwear $2.62 \pm 0.8$ and barefoot $2.46 \pm 0.92$ during the unipodal support of the Article by Alghadir et al (2018)" "effect of footwear on standing balance in healthy young adult males" and resulted in a sample of seven volunteers, and it was composed of 34 athletes, both sexes, from different sports modalities (volleyball, indoor soccer, handball, wrestling, basketball), aged between 18 and 27 years old. Athletes with ICT presented the first lateral ankle sprains for at least 12 months, with functional limitation of at least two days after sprains, evolved with a feeling of instability or ankle "cessation" and score determined by the Cumberland Ankle Instability questionnaire translated into Portuguese (CAIT-p) $<24$, presenting episodes of new sprains without removal from sports activities in the last three months, not having performed sensory or physiotherapy in the last six months. The control group was compared by athletes with no ankle pain or feeling of instability, without previous history of ankle sprains, and with scores by the CAIT questionnaire $>25$.

For exclusion criteria, pain complaints were considered at the time of evaluation or inability to perform the test, sprains recurrence with acute inflammatory signs, pain complaints in the lower limbs, surgery in the lower limb with CIT, history of fractures in the lower limb, neurological, cardiovascular, rheumatic diseases, diabetes and eversion type sprain.

Thus, the sample of 34 athletes was distributed in Group instability (GI, n=20) and Control Group (CG, n=14).

\subsection{Procedures}

Initially, the procedures and objectives of the research were explained to the athletes, who signed the free and informed consent term. Then, demographic data (age, weight, height, body mass index (BMI), level of physical activity and dominance in the lower limbs) and history of injury in the lower limbs were collected, and the athletes answered the CTIA-p. chronic ankle instability questionnaire

Then, the athlete was placed on foot for placement of surface electromyography electrodes for anterior tibial (TA) and long fibular (FL) muscles of the lower limb with chronic ankle instability for GI and lower limb preference for GC. Trichotomy was performed at the electrode placement points as well as the area cleaning with gauze friction with $70 \%$ alcohol $^{18}$. The electrodes were fixed at the previously established muscle points, according to the Surface ElectroMyoGraphy for the Non-invasive Assessment of Muscles ( SENNAM) guide, the reference electrode was fixed on the homolateral tibia anterior tuberosity.

After the electrodes were placed, the athlete was positioned with the lower limb to be tested on a step of 10 centimeters and the lunge exercise movement was performed, guided by a metronome (23 bpm) for 30 seconds, for familiarization with the test (Figure 1). For data collection, three repetitions of this test were developed with the interval of one minute of rest between each performance. Evaluations were performed by through blind evaluation. 
Figure 1 - Lunge exercise for the analysis of the anterior tibial and long fibular muscles recruitment

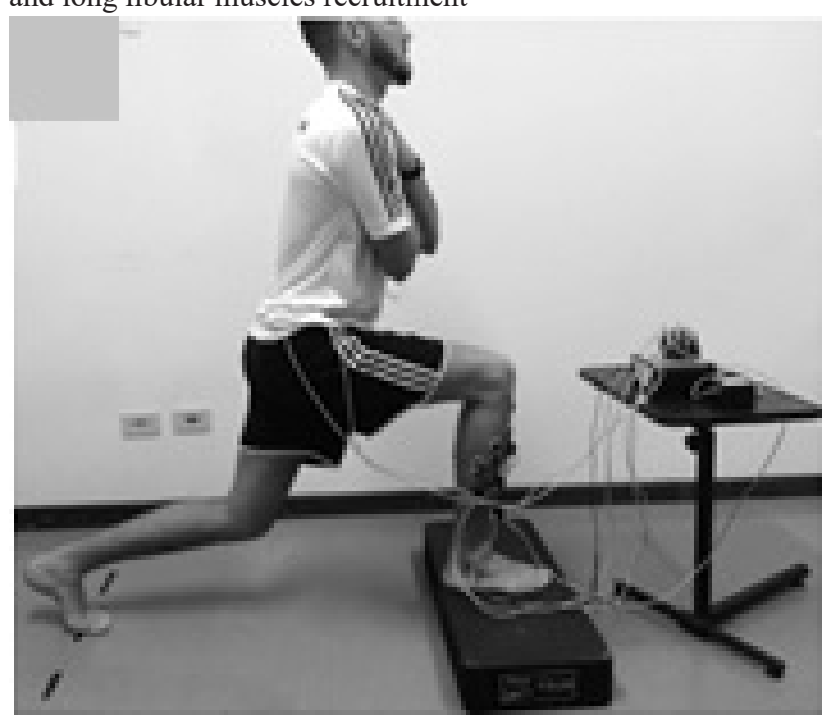

Source: The authors

Electromyographic signal collection was performed with acquisition frequency of $2000 \mathrm{~Hz}$, and high pass filters of 20 $\mathrm{Hz}$ and low pass of $450 \mathrm{~Hz}$. MATLAB 2013 software - The Language of Technical Computing software was used to analyze the electromyographic data, and the initial and final 10 seconds of the collection were eliminated. Root mean Square (RMS) was computed and normalization was established by the peak RMS signal of each muscle. As a result, the mean of the three attempts was considered.

\subsection{Statistical Analysis}

For the data normality analysis, the Shapiro-Wilk test was applied. The non-paired Student T test was used to compare the groups for the normal data analysis, as well as the presentation of their values in mean and standard deviation, and the MannWhitney test for data that do not present normal distribution with results presented in median and interquartile range. Statistical significance was 5\%, using GraphPad Prism ${ }^{\circledR} 6.1$ software.

\section{Results and Discussion}

This study aimed to evaluate the anterior tibial and long fibular muscles recruitment of athletes of various modalities, with and without ICT, during a dynamic and continuous activity with discharge of body weight (Lunge exercise), which requires the lower limb proximal and distal muscles recruitment. It is important to highlight the importance of lunge exercise, since it is used in training for athletes to prepare to strengthen the lower limbs and potentiate jumping (Bishop, et al 2017) ${ }^{19}$. The sample characterization data do not establish differences between the groups. The CAIT questionnaire presented a lower score for the group of athletes with ICT (Chart 1).

Table 1 - sample characterization and comparison between athletes with chronic ankle instability (GI) and controls (CG):

\begin{tabular}{|l|c|c|c|}
\hline \multicolumn{1}{|c|}{} & $\begin{array}{c}\text { GI } \\
\mathbf{( n = 2 0 )}\end{array}$ & $\begin{array}{c}\text { GC } \\
(\mathbf{n = 1 4})\end{array}$ & $P$ \\
\hline Male sex & 15 & 10 & - \\
\hline Female sex & 4 & 5 & - \\
\hline Age (in years) & $21.3 \pm 2.88$ & $22.4 \pm 3.25$ & 0.294 \\
\hline Height (meters) & $1,77 \pm 0,10$ & $1,74 \pm 0,08$ & 0.308 \\
\hline Weight (kilograms) & $82,6 \pm 22,19$ & $73,94 \pm 18,40$ & 0.236 \\
\hline BMI (Kg/m ) & $23,5[22,3 \pm 29,7]$ & $22,3[20,6 \pm 28]$ & 0.201 \\
\hline Training per week (in hours) & $6[4,5 \pm 8,75]$ & $4,5[4-6]$ & 0.193 \\
\hline *Cait-P & $17[12,2 \pm 19]$ & $29,5[27-30]$ & $<0.001$ \\
\hline
\end{tabular}

BMI: Body Mass Index. Cait-P - Cumberland Ankle Instability questionnaire translated into and validated to Portuguese language.

Source: Research data.

The sample was homogeneous regarding the anthropometric variables such as height, weight, age, BMI and hours of training, but presented statistical difference in the CAIT-p questionnaire score. This result was expected because it is a criterion for inclusion in the ICT group, as suggested by the International Ankle Consensus in order to standardize the studies ${ }^{11}$ Thus, CATI was sensitive to characterize individuals with functional ICT, with lower scores when compared to individuals without $\mathrm{ICT}^{11}$.

In this study, no difference was found in the recruitment of anterior tibial and long fibular muscles during the lunge dynamic movement in athletes with and without chronic ankle instability (Chart 2).

Table 2 - Comparison of anterior tibial and long fibular muscles recruitment between ICT and control groups

\begin{tabular}{|l|c|c|c|}
\hline & $\begin{array}{c}\text { GICT } \\
\text { \%RMS }\end{array}$ & $\begin{array}{c}\text { GC } \\
\text { \%RMS }\end{array}$ & $\boldsymbol{P}$ \\
\hline Anterior tibial & $111,1[62,5-165,4]$ & $106,8[79,8-230,5]$ & 0.497 \\
\hline Long fibular & $68,2 \pm 29$ & $54,4 \pm 26,4$ & 0.166 \\
\hline
\end{tabular}

GICT: Chronic ankle instability group; GC: Control group; Data presented in \% Root mean Square (RMS) normalized by peak muscle contraction.

Source: Research data. 
These results corroborate with those of De Ridder et al. ${ }^{15}$ who also did not find differences in muscle responses of individuals with and without ICT assessed on different balance surfaces and considered to be an unexpected result in the studies that indicate an increase in anterior tibial activity and a reduction in long fibular activity in athletes with ICT.

In addition, Pacheco et al. ${ }^{20}$ reported that the analysis of electromyographic response time has been used to detect the proprioceptive capacity reduction of athletes with ICT. This reduction in proprioceptive capacity should be manifested as an increase in the time of electromyographic response of the injured segment muscles. However, no statistical differences were found between athletes with and without $\mathrm{ICT}^{20}$. In this study, it was not possible to analyze the reaction time of the anterior tibial and long fibular muscles due to accelerometer interference in the electromyographic signal, which could compromise the results.

In disagreement with the results in the study herein, Koldenhovem et al. $^{4}$ demonstrated that athletes with ICT present less recruitment of the long fibular muscle, when compared to a control group, which indicates a restricted sensory-motor system, which contributes to the inability to adapt to changes in environmental demands and may increase the risk of re-injury. Also, Suda et al. ${ }^{14}$ confirmed the long fibular muscle deficit (lower root mean square response) in individuals with ICT when compared to individuals without instability during the landing of a jump and concluded that this could be the response to the maintenance of proprioceptive deficits found in individuals with ICT.

The findings of this study showed that athletes with and without ICT present the same response of anterior tibial and long fibular muscle activation during a dynamic activity with body weight discharge, which point to no differences between the groups. However, this was the only study that evaluated the muscular recruitment associated to lunge, an exercise that recruits several muscles of the lower limb, with the complex ankle/foot fixed and stable on a 10-centimeter platform, which makes it difficult to compare the results of this study with the other studies that evaluated races and jumps.

The results of the present study contribute to the clinical and sports practice, since athletes with ICT continue in constant training and seek physiotherapy for the ICT treatment and prevention. Therefore, it is worth pointing out that the use of lunge exercise did not alter the anterior tibial and long fibular muscles recruitment, which indicates the safe use of this exercise in athletes with ICT. As a limitation, it is pointed out that the time of muscle response could not be analyzed, and that the lunge exercise may not have been the best choice to request the anterior tibial and long fibular muscles in athletes with ICT, which can be considered and changed in future studies.

\section{Conclusion}

The Cait-P questionnaire established functional differences between athletes with and without chronic ankle instability, who do not present differences in the anterior tibial and long fibular muscles recruitment during the lunge exercise implementation.

Financing Body: Ministry of Education - Brazilian Federal Agency for Support and Evaluation of Graduate Education CAPES - CGC: 00.889.834/0001-08 Brasília - DF

\section{References}

1. Souza CS, Pinto GBA, Cabral TKD. Atuação da fisioterapia na prevenção da entorse de tornozelo em jogadores de voleibol: revisão bibliográfica. Pindamonhangaba: FUNVIC; 2016.

2. Waterman BR, Owens BD, Davey S, Zacchilli MA, Belmont PJ. The epidemiology of ankle sprains in the United States. J Bone Jt Surg 2010;92(13):2279-84. doi: https://doi. org/10.2106/JBJS.I.01537

3. Thompson C, Schabrun S, Romero R, Bialocerkowski A, van Dieen J, Marshall P. Factors Contributing to chronic ankle instability: a systematic review and meta-analysis of systematic reviews. Sport Med 2018;48(1):189-205. doi: https://doi.org/10.1007/s40279-017-0781-4

4. Koldenhoven RM, Feger MA, Fraser JJ, Hertel J. Variability in center of pressure position and muscle activation during walking with chronic ankle instability. J Electromyogr Kinesiol 2018;38:155-61. doi: https://doi.org/10.1016/j. jelekin.2017.12.003

5. Li Y, Ko J, Walker MA, Brown CN, Schimidt JD, Kim S, et al. Does chronic ankle instability influence lower extremity muscle activation of females during landing? J Electr. Kinesiol 2018:81-7. doi: https://doi.org/10.1016/j.jelekin.2017.11.009

6. Vomacka MM, Calhoun MR, Lininger MR, Ko J. Dorsiflexion range of motion in copers and those with chronic ankle instability. Int J Exerc Sci 201912(1):614-22.

7. Lopes B. A importância do treino proprioceptive na prevenção da entorse do tornozelo em futebolistas. Porto: Universidade do Porto; 2008.

8. Da Conceição SB, Da Silva J. Análise eletromiográfica dos músculos tibial anterior e fibular longo em portadores de entorse crônica de tornozelo. Perspectivas OnLine 2011;1(4):88-97.

9. Macedo CSG, Guergoleto-Junior C, Saenz A, De Jesus Guirro C, Rinaldo R, Frequência de instabilidade lateral crônica do tornozelo de atletas de basquetebol: análise com o questionário FAOS. ConScientiae Saúde 2012;11(1):68-75.

10. Han J, Anson J, Waddington G, Adams R, Liu Y, The role of ankle proprioception for balance control in relation to sports performance and injury. Bio Med Res Int 2015. doi: https:// doi.org/10.1155/2015/842804

11. Gribble PA, Delahunt E, Bleakley C, Caulfield B, Docherty C, Fourchet F, et al. Selection criteria for patients with chronic ankle instability in controlled research: A position statement of the International Ankle Consortium. $\mathrm{Br} \mathrm{J}$ Sports Med 2014;48(13):1014-8. doi: https://www.jospt.org/ doi/10.2519/jospt.2013.0303

12. Thain PK, Hughes GTG, Mitchell ACS. The effect of repetitive ankle perturbations on muscle reaction time and muscle activity. J Electr Kinesiol 2016:184-90. doi: https:// doi.org/10.1016/j.jelekin.2016.07.004

13. Sheng-CheYen Kevin K. Chui Ying-Chih Wang Marie B 
Corkery Mohsen Nabian Amir. An examination of muscle force control in individuals with a functionally unstable ankle. Human Mov Scie 2019:221-9. doi: https://doi. org/10.1016/j.humov.2019.02.005

14. Suda EY,Amorim CF, Sacco ICN. Influence of ankle functional instability on the ankle electromyography during landing after volleyball blocking. J Electrom Kinesiol 2009:e84-e93. doi: https://doi.org/10.1016/j.jelekin.2007.10.007

15. De Ridder R. Willems TM, Vanrenterghem, J, Roosen P. Influence of balance surface on ankle stabilizing muscle activity in subjects with chronic ankle instability. J Rehab Med 2015:632-8. doi: https://doi.org/10.2340/165019771970

16. Donnelly L, Donavan L, Hart JM, Hertel J. Eversion strength and surface electromyography measures with and without chronic ankle instability measured in 2 positions. Foot Ankle Int 2017:769-78. doi: https://doi. org/10.1177/1071100717701231
17. Alghadir AH, Zafar H, Anwer S. Effect os footware on standind balancing in healthy Young adult males. J Musculoskelet Neuronal Int 2018;18(1):71-5.

18. Moraes GFDS, Antunes AP, Rezende ES, Oliveira PCR. Avaliação da atividade eletromiográfica com ou sem o uso de diversos tipos de calçado, em diferentes planos de locomoção. Fisioter Mov 2012;25(3):507-16. doi: http:// dx.doi.org/10.1590/S0103-51502012000300006

19. Bishop CJ, Tarrant J, Jarvis PT, Tuner AN. Using the split squat to potentiate bilateral and unilateral jump performance. J Strength Conditioning Res 2017:2216-22. doi: 10.1519/ JSC.0000000000001696

20. Pacheco AM, Marco AV, Ivan P. Avaliação do tempo de resposta eletromiográfica em atletas de voleibol e não atletas que sofreram entorse de tornozelo. Rev Bras Med Esporte 2005:325-30. doi: http://dx.doi.org/10.1590/S151786922005000600004 